\title{
PENGARUH PENERAPAN MODEL PEMBELAJARAN CARD SORT TERHADAP KETERAMPILAN MENULIS SYAIR SISWA KELAS VII C SMP NEGERI 5 KOTA JAMBI TAHUN AJARAN 2017/2018
}

\author{
Abdoel Gafar ${ }^{1}$, Devila Ulfa ${ }^{2}$ \\ Program Studi Pendidikan Bahasa dan Sastra Indonesia \\ Fakultas Keguruan dan Ilmu Pendidikan Universitas Batanghari \\ Jambi \\ gafar3r@yahoo.co.id \\ u.devila@yahoo.com
}

\begin{abstract}
The purpose of this research is to describe the card sort learning model towards students class VII C writing skill at SMP Negeri 5 Kota Jambi. This research is Quasi eksperiment by using quantitative approach. This research used 1 experimental class which consists of 36 students by using Liliefors test. The requirement test used in this research is normality and homogeinity test. The result of normality pre-test is -92,48 and post-tes is -432 and the homogeinity score is 0,57 which is higher than significant $\alpha=0,05$. It means that the data is normal and homogen so that hypothesis test can be tested. Hypothesis test is done by using $t$ test formula. The result shows that the score of $t_{\text {count }}$ is 1,859 which is higher that the score of $t_{\text {table }} 1,000$ with significant $\alpha=0,05$ with $d k$ 36. It can be concluded that there is a significant correlation between the use of Card sort learning model towards students class VII C writing skill at SMP Negeri 5 Kota Jambi in which the mean category is 93,33 more higher than the mean of pre-test 76,80
\end{abstract}

Keywords: The Effect, Card Sort, Poetry Writing

\footnotetext{
${ }^{1}$ Dosen Program Studi Pendidikan Bahasa dan Sastra Indonesia, Fakultas Keguruan dan Ilmu Pendidikan, Universitas Batanghari, Jambi

${ }^{2}$ Mahasiswa Program Studi Pendidikan Bahasa dan Sastra Indonesia, Fakultas Keguruan dan Ilmu Pendidikan, Universitas Batanghari, Jambi
} 


\section{PENDAHULUAN}

Keterampilan menulis merupakan, kegiatan menuangkan ide/ gagasan seseorang untuk mencapai maksud dan tujuan dengan bahasa tulis sebagai media penyampaiannya. Keterampilan menulis tidak datang secara langsung ataupun secara tiba-tiba saja. Keterampilan menulis membutuhkan suatu proses yang menuntut sebuah pengalaman, waktu, latihan serta cara berfikir yang kritis untuk dapat menuangkan ide tersebut dalam bentuk bahasa tulis. Rofii dkk. (2018) mengatakan Writing is a complex activity requiring extensive and comprehensive knowledge (Menulis adalah kegiatan kompleks yang membutuhkan pengetahuan yang luas dan mendalam). Hal tersebut juga berlaku dalam menulis syair.

Pada kurikulum 2013 kelas VII pembelajaran menulis syair diajarkan di semester genap yaitu semester 2. Adapun Kompetensi Dasar (KD) 4.9 yiatu "Menyimpulkan isi puisi rakyat (syair) yang disajikan dalam bentuk tulisan" dengan indikator pencapaian 4.9.2 "Peserta didik mampu menulis syair”.

Berdasarkan hasil wawancara penulis dengan seorang peserta didik kelas VII C yang bernama M.Ihsan di SMP Negeri 5 Kota Jambi pada tanggal 30 November 2017, diketahui bahwa proses belajar mengajar materi menulis syair pada tahun sebelumnya, hanya diajar menggunakan model pembelajaran ceramah disertai dengan pemberian tugas saja. Akibatnya peserta didik merasa jenuh dan kurang aktif. Proses pembelajaran hanya terjadi satu arah yaitu, guru kepada peserta didik saja. Agar siswa terampil menulis, maka pembelajaran dapat diberikan oleh guru dengan cara bervariasi (Setia, Erlina Zahar, dan Ade Rahima, 2017:184).

Disisi lain, Implementasi kurikulum 2013 mengarah pada proses belajar-mengajar di kelas yang melibatkan siswa lebih aktif dan mampu menjalin komunikasi multiarah.

Salah satu cara untuk mengatasi permasalahan tersebut, digunakan model card sort sebagai bahan penelitian yang akan diterapkan dalam proses pembelajaran menulis syair. Hal ini dumaksudkan agar di dalam proses pembelajaran peserta didik dapat berpartisipasi dengan baik, dan lebih aktif.

Model pembelajaran card sort merupakan model yang tepat jika di padukan dalam materi menulis syair, model pembelajaran card sort adalah model pembelajaran menyortir kartu yang berisi materi pembelajaran yang telah disiapkan oleh guru. Pada saat penugasan kartu dibagikan secara acak pada peserta didik. Model pembelajaran yang akan diterapkan haruslah memperhatikan ketepatan dan kesesuain dengan materi dan tujuan pembelajaran yang akan diajarkan. Model pembelajaran card sort dianggap cocok jika dipadukan dengan pembelajaran menulis syair. Syair adalah jenis puisi lama yang berasal dari bahasa Arab syu'ur yang artinya perasaan, syair juga dapat diartikan sebagai ekspresi perasaan atau pemikiran dari pembuatnya.

Pertimbangan pemilihan model card sort dalam pembelajaran menulis syair adalah karena kurang bervariasinya model yang diterapkan oleh guru mata pelajaran bahasa Indonesia pada pembelajaran menulis syair. model pembelajaran card sort ini dapat mengurangi rasa jenuh siswa dalam kegiatan menulis syair, karena card sort dapat membuat suasana kelas menjadi lebih menyenangkan. Model card sort juga belum pernah diterapkan di SMP Negeri 5 Kota Jambi pada materi syair, sehingga sangat tepat apabila penelitian mengenai penerapan model card sort terhadap pembelajaran syair ini dilaksanakan.

Berdasarkan latar belakang tersebut, penelitian ini memfokuskan kajiannya pada penerapan model card sort 
terhadap keterampilan menulis syair siswa kelas VIIC SMP Negeri 5 Kota Jambi Tahun Ajaran 2017/2018.

Penelitian ini berusaha untuk menjawab pertanyaan bagaimanakah pengaruh model pembelajaran card sort terhadap keterampilan menulis syair siswa kelas VIIC SMP Negeri 5 Kota Jambi Tahun Ajaran 2017/2018? Selain itu penelitian ini bertujuan untuk membuktikan apakah model pembelajaran card sort berpengaruh terhadap keterampilan menulis syair siswa kelas VII C di SMP Negeri 5 Kota Jambi tahun ajaran 2017 /2018.

\section{Kajian Pustaka}

Menurut Aunurrahman (2012:48) "Belajar adalah perubahan tingkah laku yang relatif tetap dan terjadi sebagai hasil latihan atau pengalaman”.Selanjutnya Rusman (2012:12) menjelaskan bahwa belajar adalah salah satu faktor yang mempengaruhi dan berperan penting dalam pembentukan dan prilaku individu”. Maka dari itu seseorang harus melalui proses demi proses pembelajaran agar terbentuk sikap dan pribadi yang lebih baik.

Pembelajaran merupakan kegiatan yang terjadi antara guru dan siswa. "Pembelajaran merupakan proses komunikasi dua arah, mengajar dilakukan oleh guru sebagai pendidik, sedangkan belajar dilakukan oleh peserta didik atau murid” (Sagala, 2013:61). Pembelajaran dirancang agar siswa lebih aktif dalam proses belajar mengajar yang didukung oleh sumber yang mmemadai. Pembelajaran merupakan suatu sistem, yang terdiri atas berbagai komponen yang saling berhubungan satu dengan yang lain” (Rusman, 2012:1).

Menurut Sayuti (2009:133)

“Apresiasi sastra adalah sebuah hasil usaha dari seseorang pembaca dalam menemukan atau mencari suatu nilai hakiki karya sastra melalui pemahaman dan penafsiran secara sistematik”. Pembelajaran apresiasi sastra. "Apresiasi sastra adalah memahami dan menyenangkan, meletakkan penghargaan nilai yang tinggi, mengenal dan mengerti secara sopan, menjadi peka, menaksir dan menghargai dengan kritis” (Muksin,1989:86). Menurut Hayati dan Muslich (2015:5) “Apresiasi sastra adalah penghargaan, penilaian dan pengertian terhadap karya sastra, baik yang berbentuk puisi maupun prosa. Belajar apresiasi sastra pada hakikatnya mengajarkan tentang hidup dan kehidupan. Menurut Rahmawati (2010:1) "Sastra bisa dibagi menjadi sastra tulis dan sastra lisan”.

Menurut Hamid dalam Karim (1998:148) "Kata syair berasal dari bahasa Arab yang telah diterima dalam bahasa Indonesia. Sebutan yang betul bagi perkataan itu dalam bahasa Arab ialah syi'ir yang berarti 'puisi', 'sajak'. Dalam kesusastraan Arab syi'ir ialah bentuk yang telah muncul sejak zaman pra-Islam dan berkembang menjadi satu bentuk puisi yang populis dikalangan orang Arab sejak zaman sebelum dan sesudah kedatangan agama Islam.

Dalam Kamus Besar Bahasa Indonesia (2013:1367) disebutkan bahwa "Syair adalah puisi lama yang berakhir dengan bunyi sama”. Syair merupakan bentuk puisi klasik yang merupakan pengaruh kebudayan Arab (Kosasih, 2012:17). Syair masuk kedalam jenis puisi lama yang mana siswa belum terlalu dominan mengenalnya selama ini.

Menurut Damayanti (2013:102) syair memiliki ciri-ciri antara lain: (1) setiap bait terdiri dari empat baris (2) setiap baris terdiri atas 8-14 suku kata (3) bersajak a-a-a-a (4) semua baris adalah isi (5) bahasanya biasanya kiasan. Damayanti (2013:104) juga membedakan syair menjadi lima golongan yaitu, (1) syair panji (2) syair romantis (3) syair kiasan (4) syair sejarah (5) syair agama. 
Model pembelajaran card sort merupakan model yang memanfaatkan beberapa kartu yang disiapkan guru berisikan materi pelajaran. Menurut Silberman (2009:157) "Model pembelajaran card sort atau memilih dan memilah kartu, merupakan kegiatan kolaborasi yang bisa digunakan untuk mengajarkan konsep, penggolongan sifat, fakta tentang suatu objek, atau mengulangi informasi. Gerakan fisik yang diutamakan dapat membantu untuk memberi energi kepada kelas yang telah letih”.

Senada dengan pendapat di atas Silberman (2009:169). "Metode pembelajaran card sort adalah aktivitas kerja sama yang bisa digunakan untuk mengerjakan konsep, karakteristik, klasifikasi, fakta tentang benda, atau nilai informasi, gerak fisik di dalamnya dapat membantu siswa menghilangkan kejenuhan.

Selanjutnya Silberman (2013:169) memaparkan proses pelaksanaan pemebalajaran dengan model card sort, dijelaskan sebagai berikut.

1) Berilah masing-masing peserta didik kartu indeks yang berisi informasi atau contoh dengan satu atau lebih kategori.

2) Mintalah peserta didik untuk berusaha mencari temannya di ruang kelas dan menemukan orang yang memiliki kartu dengan kategori sama (anda bisa mengumumkan kategori tersebut sebelumnya atau biarkan peserta didik mencarinya sendiri).

3) Biarkan peserta didik dengan kartu kategorinya yang sama menyajikan sendiri pada orang lain.

4) Selagi masing-masing kategori dipresentasekan (buatlah beberapa poin mengajar yang anda rasa penting).

Menurut Wiyatmi (2006:58), aspekaspek yang dinilai dalam keterampian menulis syair adalah: (1) kesesuaian tema, (2) rima, (3) ketepatan diksi, (4) pencitraan.
Beberapa penelitian terdahulu yang relevan dengan penelitian ini, dijelaskan sebagai berikut. Pertama, penelitian yang dilakukan oleh Umi Suryani (2014) dengan judul skripsi "Upaya Meningkatkan Kemampuan Membaca Melalui Metode Card Sort pada Pelajaran Bahasa Indonesia bagi Siswa Kelas 1 MIN Wonosari Kabupaten Gunungkidul Yogyakarta Tahun Ajaran 2013/2014”. Kedua, penelitian yang dilakukan oleh Arif Saifullah tahun 2010, dalam skripsi yang berjudul "Penerapan Model Pembelajaran Aktif Tipe Pemilahan Kartu (Card Sort) untuk Meingkatkan Keefektifan dan Prestasi Belajar Siswa Kelas VII dalam Pembelajaran Fiqih di MTS Tarbiyaatul Islamiah Pati”. Ketiga, penelitian yang dilakukan oleh Erlita Winda Khrisyanti tahun 2014 dalam skripsinya yang berjudul "Peningkatan Keterampilan menulis Puisi Melalui Penerapan Model Active Learning Card Sort Siswa Kelas VA SD 1 Pedes Kecamatan Sedayu Kabupaten Bantul Tahun Ajaran 2013/2014”.

\section{METODE PENELITIAN}

Jenis penelitian ini adalah penelitian kuantitatif. Penelitian ini dilakukan dengan menggunakan metode quasi eksperimen (eksperimen semu). Menururt Sugiyono (2014:114) "Desain ini mempunyai kelompok kontrol, tetapi tidak dapat berfungsi sepenuhnya untuk mengontrol variabel-variabel luar yang mempengaruhi pelaksanaan eksperimen. Sedangkan menurut Arikunto (2010:207) "Penelitian quasi eksperimen merupakan penelitian yang tidak memenuhi seluruh persyaratan yang ditetapkan dalam penelitian murni”. Adapun teknik penentuan sampel menggunakan teknik total sampling. Total sampling adalah teknik pengambilan sampel dimana jumlah sampel sama dengan populasi (Sugiyono, 20014:61).

"Instrumen penelitian adalah alat bantu yang yang digunakan oleh peneliti

Pengaruh Penerapan Model Pembelajaran Card Sort terhadap Keterampilan Menulis Syair Siswa Kelas VII C SMP Negeri 5 Kota Jambi Tahun Ajaran 2017/2018 
dalam mengumpulkan data” (Arikunto, 2014:131). Dalam penelitian ini instrumen yang digunakan berupa tes penugasan menulis syair. Tes dilakukan untuk mengetahui hasil belajar yang diperoleh siswa setelah memperoleh perlakuan. Prosedur penelitian dilakukan dengan cara pemberian perlakuan (treatmen) berupa penerapan model card sort pada tahap post-test.

\section{HASIL DAN PEMBAHASAN}

Berdasarkan penerapan model card sort dalam pembelajaran menulis syair yang telah dilakukan, diketahui bahwa keterampilan menulis syair siswa kelas VII C SMP N 5 Kota Jambi yang menggunakan model card sort lebih baik dibandingkan hasil pretest tanpa menggunakan model. Berdasarkan nilai rata-rata kelas terlihat bahwa keterampilan menulis syair siswa yang diberi perlakuan menggunakan model pembelajaran card sort lebih baik dari pada yang tidak. Hal ini terlihat dari nilai rata-rata yang diperoleh kelas eksperimen pada post-test adalah 93,33 lebih besar dari nilai rata-rata pre-test 76,80

1. Keterampilan menulis syair siswa kelas VIIC SMP Negeri 5 Kota Jambi berdasarkan hasil pre-test

Berdasarkan hasil analisis data terlihat bahwa nilai rat-rata pre-test adalah 76,80. Terlihat rata-rata untuk tiap butir soal. Pada butir soal pertama, diperoleh nilai rata-rata 4 (baik). Pada butir soal kedua, diperoleh rata-rata 3 (cukup). Pada butir soal ketiga, diperoleh nilai rata-rata 3 (cukup). Pada butir keempat, diperoleh nilai rata-rata 3 (cukup).

2. Keterampilan menulis syair siswa kelas VIIC SMP Negeri 5 Kota Jambi berdasarkan hasil post-test

Berdasarkan hasil analisis data, terlihat bahwa nilai rata-rata post-test adalah 93,33. Terlihat rata-rata untuk tiap butir soal. Pada butir soal pertama, diperoleh nilai rata-rata 5 (sangat baik). Pada butir soal kedua diperoleh nilai rata-rata 4 (baik). Pada butir soal ketiga, diperoleh nilai rata-rata 4 (baik). Pada butir soal keempat, diperoleh nilai rata-rata 4 (baik). Berdasarkan uji hipotesis yang telah dilakukan terlihat bahwa nilai rata-rata siswa yang diajarkan dengan menggunakan model card sort lebih tinggi yaitu 93.33, dari pada nilai rata-rata siswa yang diajarkan tanpa menggunakan model card sort yaitu 76.80.

Berdasarkan nilai yang telah didapat, dilakukan uji normalitas dengan menggunakan uji Lilefors. Berdasarkan uji normalitas yang telah dilakukan di peroleh nilai pre-test sebesar $F_{\text {tabel }}=-92,48<11$, dan nilai post-tes sebesar adalah -432 dari taraf signifikan $\alpha=0,05$, shingga dapat disimpulkan bahwa data dalam penelitian ini distribusi normal.

Berdasarkan uji homogenitas yang telah dilakukan diperoleh nilai $F_{\text {hitung }}$ $0,57$ dari taraf signifikansi ( $\alpha=0.05)$ dengan $F_{\text {hitung }}=$ dengan $d k_{\text {pembilang }} 36-$ $1=35$ dengan $F_{\text {tabel }}=2,0226$. Maka dapat disimpulkan $F_{\text {hitung }}<F_{\text {tabel }}$.

Berdasarkan uji normalitas dan homogenitas, diperoleh hasil bahwa kedua sampel berasal dari populasi yang berdistribusi normal dan kedua varians populasi homogen, maka selanjutnya dapat dilakukan uji hipotesis. Pengujian hipotesis dilakukan untuk mengetahui apakah penggunaan model Card sort berpengaruh dalam menulis syair. Dalam penelitian ini uji hipotesis menggunakan uji t. Statistik penelitian ini adalah

$H_{o}: \mu_{1}=\mu_{2}$ dan $H_{o}: \mu_{1} \geq \mu_{2}$.

Dari hasil perhitungan uji t, diperoleh $t_{\text {hitung }}$ sebesar 1.859 untuk nilai $t_{\text {tabel }}$ diperoleh dari t dengan $\mathrm{dk} 70$ dan taraf

Pengaruh Penerapan Model Pembelajaran Card Sort terhadap Keterampilan Menulis Syair Siswa Kelas VII C SMP Negeri 5 Kota Jambi Tahun Ajaran 2017/2018 
signifikansi ( $\alpha=0,05)$, yaitu sebesar 1.000 . Dengan membandingkan nilai $t_{\text {hitung }}>t_{\text {tabel }}$ hal ini berarti $H_{o}$ ditolak dan $H_{a}$ diterima.

Dapat dikatakan bahwa model card sort berpengaruh secara signifikan terhadap pembelajaran menulis syair, dilihat dari peningkatan nilai rata-rata yang naik sebanyak 16.53 .

Dalam proses pembelajaran menulis syair, siswa yang diajarkan dengan menggunakan model card sort nampak lebih antusias, aktif dan kreatif dari pada siswa yang diajarkan tidak menggunakan model card sort. Karena pada pembelajaran yang menggunakan model card sort siswa ikut berperan aktif dan terjadi pembelajaran secara dua arah.

Dalam proses pembelajaran dengan menggunakan model card sort, nampak jelas perbedaannya antara sebelum dan sesudah materi diberikan menggunakan model, card sort. Sebelum materi diberikan menggunakan model cart sort siswa hanya pasif, pembelajaran hanya berpusat pada guru. Hal ini membuat siswa jenuh.

$\begin{array}{ccc}\text { Setelah } & \text { diberikan materi } \\ \text { menggunakan model card sort }\end{array}$ pembelajaran terjadi secara dua arah karena siswa juga terlibat aktif di dalam proses pembelajaran. Sebelum materi disampaikan siswa telah diinstruksikan bahwa pembelajaran akan dilaksanakan menggunakan model card sort, meskipun sebelumnya mereka belum mengetahui apa itu model card sort.

\section{SIMPULAN}

Berdasarkan dari hasil analisis data yang telah dilakukan, nilai nilai rata-rata post-test 93,33 lebih tinggi dari nilai ratarata pre-test 76,80. Selain itu dari segi aspek yang dinilai, tingkat keberhasilan peraspek post-test lebih baik dari pre-test. Untuk aspek pertama diperoleh nilai rata- rata 5 (sangat baik). Pada butir soal kedua diperoleh nilai rata-rata 4 (baik). Pada butir soal ketiga, diperoleh nilai rata-rata 4 (baik). Pada butir soal keempat, diperoleh nilai rata-rata 4 (baik). Selanjutnya keberhasilan peraspek pre-test pada butir soal pertama, diperoleh nilai rata-rata 4 (baik). Pada butir soal kedua, diperoleh rata-rata 3 (cukup). Pada butir soal ketiga, diperoleh nilai rata-rata 3 (cukup). Pada butir keempat, diperoleh nilai rata-rata 3 (cukup).

Berdasarkan pengujian hipotesis diperoleh kesimpulan bahwa penggunaan model pembelajaran Card sort berpengaruh secara signifikan terhadap keterampilan menulis syair siswa kelas VII C SMP Negeri 5 Kota Jambi tahun ajaran 2017/2018. Hal ini dibuktikan dengan pengujian hipotesis menggunakan uji t. Dalam pengujian hipotesis di peroleh nilai $t_{\text {hitung }}$ sebesar 1,859 lebih besar dari nilai $t_{\text {tabel }}$ dengan $\mathrm{dk} 70$ sebesar 1,000 yang artinya $H_{a}$ diterima. Dengan demikian model Card sort dapat digunakan atau diterapkan dalam pembelajaran menulis menulis syair. .

\section{DAFTAR PUSTAKA}

Arikunto, Suharsimi. (2010). Manajemen Penelitian: Suatu Pendekatan Praktif. Jakarta : Rineka Cipta.

Arikunto, Suharsimi. (2014). Prosedur Penelitian: Suatu Pendekatan Praktis. Jakarta : Rineka Cipta.

Aunurrahman. (2012). Belajar dan Pembelajaran. Bandung: Alfabeta.

Damayanti, D. (2013). Buku Pintar sastra Indonesia: Puisi, Sajak, Syair, Pantun dan Majas.Yogyakarta. Araska.

Hayati, A. Mansur Muslich. Latihan Apresiasi Sastra. Surabaya: Triana Media.

Kamus Besar Bahasa Indonesia Edisi 3. (2013). Jakarta: Balai Pustaka

Karim, Maizar. (2015). Menyelisik Sastra Melayu. Yogyakarta: Histokultura.

Pengaruh Penerapan Model Pembelajaran Card Sort terhadap Keterampilan Menulis Syair Siswa Kelas VII C SMP Negeri 5 Kota Jambi Tahun Ajaran 2017/2018 
Khrisyanti, Erlita Winda, (2014) dalam "Peningkatan Keterampilan menulis Puisi Melalui Penerapan Model Active Learning Card Sort Siswa Kelas VA SD 1 Pedes Kecamatan Sedayu Kabupaten Bantul Tahun Ajaran 2013/2014”. Skripsi.

Kosasih. (2012). Dasar-dasar Keterampilan Bersastra. Bandung: Yrama Widya.

Muksin, Ahmad. (1989). Keterampilan Berbahasa dan Apresiasi Sastra. Malang: YAS Malang.

Rahmawati, Lila Dewi. (2010). Pengantar Apresiasi Sastra. Jakarta: CV Balai Pustaka

Rofii, A., Murtadho, F., Rahmat, A. (2018) "Model of Contextual-Based Academic Writing Learning Module (R\&D At Faculty of Teacher Training And Education Universitas Batanghari Jambi)" English Review: Journal of English Education, vol. 6, no. 2 pp 51-60. Doi: $\quad$ 10.25134/erjee.v6i2.1242. (https://www.journal.uniku.ac.id/in dex.php/ERJEE/article/view/1242

Rusman. (2012). Model-model Pembelajaran. Jakarta: PT Raja Granfindo Persada.

Sagala, Syaiful. (2013). Kumpulan Sastra Indonesia. Pantun, Puisi, Peeribahasa, Kata Mutiara: PT. Buku Kita.

Saifullah, Arif (2010), "Penerapan Model Pembelajaran Aktif Tipe Pemilihan Kartu (Card Sort) Untuk Meningkatkan Keafektifan dan Prestasi Belajar Siswa kelas VII dalam pembelajaran Fiqih di MTS Tarbiyatul Islamiyah Pati”. Skripsi.

Sayuti, A Suminto. (2009). Pengantar Apresiasi Karya Sastra. Bandung: Sinar Baru.

Setia, R. B. J., Zahar, E., \& Rahima, A. (2018). Penggunaan Media Lagu Pop dalam Pembelajaran Menulis Cerpen Realis Siswa Kelas IX A SMP Negeri 9 Kota Jambi Tahun Pelajaran 2016/2017. Aksara: Jurnal Ilmiah Pendidikan Bahasa dan Sastra Indonesia, 2(1), 183191.

Silberman, Melvin.L. (2009). Active Learning 101 Cara Belajar Siswa Aktif. (Alih Bahasa: Raisul Muttaqien).

Silberman, Melvin.L. (2013). Active Learning 101 Cara Belajar Siswa Aktif. (Alih Bahasa: Raisul Muttaqien).

Sugiyono. (2012). Metode Penelitian Pendidikan: Pendekatan Kuantitatif, Kualitatif dan $R \& D$. Bandung: Alfabeta.

Sugiyono. (2014). Metode Penelitian Pendidikan: Pendekatan Kuantitatif, Kualitatif dan $R \& D$. Bandung: Alfabeta.

Suryani, Umi. (2014). “Upaya Meningkatkan Kemampuan Membaca Melalui Metode Card Sort Pada Pelajaran Bahasa Indonesia Bagi Siswa Kelas 1 MIN Wonosari Kabupaten Gunungkidul Yogyakarta Tahun Ajaran 2013/2014”. Skripsi.

Wiyatmi. (2006). Pengantar Kajian Sastra. Yogyakarta: Pustaka. 